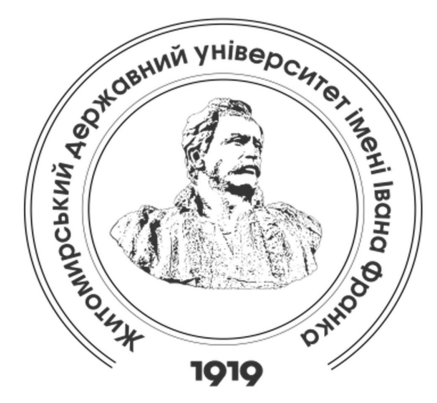

Zhytomyr Ivan Franko State University Journal. Pedagogical Sciences. Vol. 2 (105)

Вісник Житомирського державного університету імені Івана Франка. Педагогічні науки. Вип. 2 (105)

ISSN (Print): 2663-6387

ISSN (Online): 2664-0155

\title{
UDC 53-047.42:373.015.31 \\ DOI 10.35433/pedagogy.2(105).2021.26-34 \\ FORMATION OF PRACTICAL SKILLS IN STUDENTS WITH THE HELP OF EXPERIMENTAL PROBLEMS IN PHYSICS
}

\section{S. A. Poletylo*}

The article introduces one of the ways to form students' practical skills by solving experimental problems focused on a specific practical method that can be successfully used to solve life's cognitive problems. The introduction of the proposed approach was preceded by the study of the opinions of physics teachers of secondary schools in the Volyn region of Ukraine. The attitude and wishes of students from the same region to solving experimental problems are clarified.

The definition of experimental problems is offered as follows: these are the problems with the data taken from the experiment to obtain a solution.

The solution of experimental problems is considered as a part of educational physical experiment, which is an essential component of the methodical system of teaching physics, as it provides the formation of the necessary practical and research skills.

A series of experimental problems that provide the formation of practical skills of students on the example of educational material devoted to the study of the concept of "density of matter". A solution is proposed for each problem. The views of scientists on the problem of using experimental problems in the practice of physics lessons are reflected; the difficulties that teachers face when using the mentioned type of tasks are outlined. A study of corresponding textbooks in recent years on the problem of using experimental problems in the practice of teaching students is conducted.

Methodical recommendations on the choice of time for solving the given series of experimental problems, forms of work of students in a modern physics lesson are offered.

Attention is paid to the selection and solution of experimental problems of other educational material related to the concept of "density of matter", the place and forms of their solution in the practice of the lesson are substantiated.

The effectiveness of the proposed approach to solving experimental problems on the basis of expert evaluation is established.

Key words: basic school, modern physics lesson, practical methods, forms of teaching, educational physical experiment, pedagogical experience.

\footnotetext{
* Candidate of Pedagogical Sciences (PhD in Pedagogy), Associate Professor

(Lesya Ukrainka Volyn National University)

spolet@bigmir.net
}

ORCID: 0000-0003-4919-1891 


\section{ФОРМУВАННЯ ПРАКТИЧНИХ УМІНЬ В УЧНІВ ЗА ДОПОМОГОЮ ЕКСПЕРИМЕНТААЬНИХ ЗАДАЧ З ФІЗИКИ}

\section{С. А. Пометимо}

У статті представлено один із способів формування практичних умінь учнів шияхом вирішення експериментальних задач, орієнтованих на конкретний практичний метод, який можна успішно використовувати для вирішення життєвих пізнавальних проблем. Впровадження запропонованого підходу передувало вивчення думок вчителів фізики загальноосвітніх шкіл Волинської області України. З'ясовано ставлення та побажання студентів з того ж регіону до вирішення експериментальних задач.

Визначення експериментальних задач пропонуеться таким чином: ие ті задачі, дані яких взяті з експерименту для отримання розв'язку.

Розв'язання експериментальних задач розглядається як частина навчального фрізичного експерименту, який $є$ органічною складовою методичної системи навчання фрізики, оскільки забезпечуе формування необхідних практичних умінь та навичок дослідження.

Наведено низку експериментальних задач, що забезпечують фрормування практичних навичок учнів на прикладі навчального матеріалу, присвяченого вивченню поняття "густина речовини". Для кожної задачі пропонується розв'язок. Розкрито погляди вчених на проблему використання експериментальних задач у практииі уроків фрізики; помічені труднощі, з якими стикаються вчителі під час використання зазначеного типу задач. Досліджено підручники фрізики останніх років щодо проблеми використання експериментальних задач у практииі навчання учнів.

Запропоновано методичні рекомендації щодо обрання часу на розв'язання заданої серії експериментальних задач, форми роботи учнів на сучасному уроиі фрізики.

Звернуто увагу на відбір та розв'язання експериментальних задач іншого навчального матеріалу, пов'язаного з поняттям "густина речовини", обгрунтовано місие та фоорми їх розв'язання в практииі уроку.

Встановлено ефрективність запропонованого підходу до розв'язання експериментальних задач на основі експертної оцінки.

Ключові слова: базова школа, сучасний урок фрізики, практичні методи, форми навчання, навчальний фізичний експеримент, педагогічний досвід.

Introduction of the issue. The main role in the formation of practical skills of students of secondary schools is played, according to the current program, by educational physical experiment [1: 13]. Thanks to the acquired practical skills during the whole period of study, students will be able to solve cognitive tasks in later life. Among the variety of forms of implementation of educational physical experiment for the formation of practical skills, a significant role is played by solving such experimental problems, the solution of which requires a specific method that can be successfully used to solve life's cognitive problems. Most physics teachers in the Volyn region agree with this conclusion. Experimental problems include those, whose data was collected during the experiment to obtain a solution.

Current state of the issue. The issue of using experimental problems in the practice of elementary school physics lessons is not new and has been considered by many scientists. Similar vision of the possibility of using experimental problems in physics to form practical skills is shared by many scientists. Different approaches to the use of these tasks in the practice of modern physics lessons have been singled out.

According to a group of scientists (Gaiduchok V.M., Nyzhnyk V.G., Kulyk L.O. [2-3]) it is advisable to solve experimental problems during laboratory work. The main argument for this approach is the ability to use equipment for laboratory work and the 
available time reserve for such lessons. Other scientists (Ivanenko O.F., Makhlay V.P., Bogatyrev O.I. [4], Goncharenko S.U., Korshak E.V., Korshak N.M. [5; 6]) believe that experimental physics problems should be used on a par with quantitative and qualitative problems. In their opinion, experimental problems are a criterion for identifying the talents of students in physics.

Another group of scientists (Galatyuk Y.M., Rybalko A.V., Tyschuk V.I. [7]) proceed from the position that experimental problems have the structure of scientific research, and therefore in addition to the usual experimental issues (using specific devices to determine certain value or prove the fact), it is necessary to increase the number of experimental problem-based taks that require a research approach.

Analysis of 7 th grade physics textbooks of Bozhinova F.Y. elementary school [8], Korshak E.V. [9], Serdyuk V.D. [10] showed a steady increase in the number of experimental tasks for students, which are of significant importance for the formation of practical skills.

Aim of research is to introduce one of the ways to develop students' practical skills by solving experimental problems focused on a specific practical method that can be successfully used in adult life.

Results and discussion. Study was conducted among physics teachers in the Volyn region and it has confirmed that experimental tasks occupy a morminent place among the factors that ensure the formation of students' necessary practical skills. The survey indicated that teachers: 1) occasionally use experimental problems solving tasks during the lessons; 2) do not follow a single approach to the use of problems of this type in the teaching of physics. Most often, their use is reduced to repetition, consolidation and generalization of the studied aimed at developing students' interest, acquiring skills to use devices, as well as to assess the quality of acquired knowledge, etc.; 3) spend too much time to select this type of task from different sources; 4) when using experimental problems focus on the existing material base; 5) need a collection of tasks in which this type of task would be located on the topics of the current program.

The vast majority of interviewed students in grades 7-9 of Volyn region are interested in solving experimental problems. They note that after solving such problems, the studied material becomes more understandable and memorable for a long time. In addition, students emphasize the acquisition of skills that they will need in adulthood. Students agree that they want to solve experimental problems more often in class.

Taking into account the opinions of teachers and the wishes of students, in the selection and use of experimental problems in physics lessons we focus not on the fact of their use in the educational process, but on such exploitation, which forms practical (emphasized - S.P.) skills needed in later life and the ability to experiment. We focus on the disclosure and mastery of the practical method of cognition; a method that brings closer to the real conditions of human life and encourages the use of physics in a reallife situation.

Let's illustrate this with an example of a series of experimental problems related to the concept of "density of matter".

Problem № 1 (illustrates a practical method for determining the substance of the body). Identify the metal from which the body is made of.

Equipment: beaker with water, thread, scales with a set of weights, textbook.

The solution. If the density of the metal is known, then the density table determines which metal it is. The 
density of the metal is found based on the formula of density:

$$
\rho=\frac{m}{V}
$$

The mass $\mathrm{m}$ of a body is found by weighing, and its volume $\mathrm{V}$ by a beaker.

Problem № 2 (illustrates a practical method for determining the substance of a metal wire). Determine the metal from which the wire is made.

Equipment: a skein of wire; roulette; student ruler, scales with weights.

The solution. The metal from which the wire is made is searched using the density table given in the textbook. The density of the substance is found as follows:

$$
\rho=\frac{m}{V}
$$

The mass of the wire $m$ is found by weighing the wire, and the volume $\mathrm{V}$ is found as the volume of the cylinder: the area of the base $\mathrm{S}$ is multiplied by the height of the cylinder $\ell$, that is:

$$
V=S l
$$

It is known that the cylinder is based on a circle, therefore:

$$
S=\frac{\pi d^{2}}{4}
$$

Residual:

$$
\rho=\frac{m}{\pi l d^{2}}
$$

The diameter of the wire $d$ is found using a ruler, and the length of the wire $\ell$ - with a tape measure.

Problem № 3 (illustrates a practical method of determining the length of the wire in the skein, when it is impossible to unwind the wire). Determine the length of the copper wire in the skein without unwinding it.

Equipment: a skein of copper wire; scales with weights; calipers.

The solution. If the wire was unwound, it would have the shape of a cylinder with height $\ell$ and area of the base $\mathrm{S}$. The volume of this cylinder would be:

$$
V=\ell S
$$

The mass of the wire $m$ can be represented by the density $\rho$ and the volume V:

$$
m=\rho V
$$

Given both expressions:

$$
m=\rho \ell S
$$

The basis of the cylinder is a circle, so its area is sought as follows:

$$
S=\frac{\pi d^{2}}{4} \text {. }
$$

After substitution find:

$$
m=\frac{\rho \pi d^{2}}{4} \ell
$$

where:

$$
\ell=\frac{4 m}{\rho \pi d^{2}}
$$

The mass of the skein $\mathrm{m}$ is sought by weighing, the diameter of the wire $d$ is measured with a caliper.

Problem № 4 (illustrates a practical method for determining the thickness of thin plates). Determine the thickness of the aluminum foil.

Equipment: rectangular aluminum foil; student line; scales with a set of weights; textbook.

The solution. The mass of foil $\mathrm{m}$ through the density $\rho$ and the volume $\mathrm{V}$ is expressed as follows:

$$
m=\rho \mathrm{V}
$$

The volume of the foil is sought as the volume of the parallelepiped:

$$
V=a b h
$$

where $a$ is the length, $b$ is the width, and $h$ is the thickness of the foil. Take into account the last expression and get:

Residual:

$$
m=\rho a b h
$$

$$
h=\frac{m}{\rho a b} .
$$

The mass of the foil is found by weighing, the length and width of the foil is measured with a ruler; the density of aluminum is sought according to the table of densities of the textbook. 
Problem № 5 (illustrates a practical method of determining the volume of a vessel). Determine the volume of the glass.

Equipment: test glass; scales with weights; water.

The solution. The volume of the glass $\mathrm{V}$ is found through the volume of water that completely fills the vessel:

$$
V=\frac{m_{b}}{\rho}
$$

where $\rho$ is the density of water.

The mass of water $m_{B}$ is found as the difference between the mass of a glass of water $m_{1}$ and a glass without water $\mathrm{m}_{2}$, which are sought by weighing:

$$
m_{6}=m_{1}-m_{2} \text {. }
$$

Problem № 6 (illustrates a practical method for determining the volume of the cavity). Determine the volume of the glass ball cavity.

Equipment: glass ball having a cavity; scales with weights; beaker with water; textbook.

The solution. The volume of the cavity $\mathrm{V}$ can be found as the difference between the volume of the sphere $V_{1}$ (if there were no cavity) and the volume of the glass $\mathrm{V}_{2}$ :

$$
V=V_{1}-V_{2}
$$

The volume of the sphere $V_{1}$ is sought by means of a beaker with water, and the volume of the glass $V_{2}$ by weighing $(\mathrm{m})$ and taking into account the density of the glass $(\rho)$ :

$$
V_{2}=\frac{m}{\rho} \text {. }
$$

The given series of experimental problems is focused on the formation of methods that can be successfully used to solve life's cognitive problems. What these tasks have in common is that they focus on material devoted to the study of the concept of "density of matter".

In order for each student to master all the practical methods of this series of tasks, it is advisable in the next lesson to solve these problems in student groups. The teacher divides the class into groups of 3-4 students, each group offers one of the tasks of the series. The experimental task takes 1215 minutes. After the allotted time, the representatives of the groups report on the method that they will be able to use in later life to find a certain value (10 minutes). With this approach, all students will get acquainted with the method, saving lesson time to study the next program topic.

In the further study of the educational material, experimental tasks are also used, focused on mastering a certain practical method, including those with a previously mastered concept (in particular, "density of matter"). An example of such tasks can be the following (follow the numbering of tasks - S.P.).

Problem № 7 (illustrates a practical method of determining the volume of a stone without using a beaker). Find the volume of the stone.

Equipment: stone; dynamometer; vessel with water.

The solution. The stone is weighed twice: in air (find the mass $\mathrm{m}_{1}$ ) and in water (find the mass $\mathrm{m}_{2}$ ). Express the second mass through the first and find:

$$
V=\frac{m_{1}-m_{2}}{\rho_{B}} \text {. }
$$

Problem № 8 (illustrates a practical method for determining the type of unknown liquid). Determine the type of liquid.

Equipment: beaker with water; a glass of water; a glass with an unknown liquid; ruler; test tube, textbook.

The solution. The test tube is half filled with water and immersed in a beaker of water. Record the height of its immersion $h_{1}$ and the height of the water column in it $h_{2}$. Repeat the experiment with an unknown liquid: it is poured into a test tube so that the depth of immersion of the beaker was also $h_{2}$. Measure the height of the column of unknown liquid $h_{3}$. For both cases, record the swimming condition: 
and

$$
P_{1}+P_{2}=\rho g V_{1}
$$

$$
P_{1}+P_{3}=\rho g V_{1}
$$

here $\mathrm{P}_{1}, \mathrm{P}_{2}, \mathrm{P}_{3}$ is the weight of the test tube, the weight of the water in the test tube, the weight of the unknown liquid in the test tube, respectively; $\rho$ water density; $\mathrm{V}_{1}$ - the volume of water displaced by the test tube. Solve the system of equations and find:

$$
P_{2}=P_{3} \text {. }
$$

Or:

$$
m_{2}=m_{3}
$$

Accordingly:

$$
\rho V_{2}=\rho_{3} V_{3} .
$$

Take into account the uniformity of the cross section of the test tube in both cases, get:

$$
\rho h_{2}=\rho_{3} h_{3} .
$$

From:

$$
\rho_{3}=\frac{\rho}{h_{3}} h_{2}
$$

Problem № 9 (illustrates a practical method for determining the type of unknown liquid). Determine the type of liquid.

Equipment: dynamometer; steel cylinder with hook; a glass with an unknown liquid; ruler; textbook.

The solution. Using a dynamometer, weigh the cylinder for the first time in the air and find its weight $P$, then - in the liquid and find its weight $\mathrm{P}_{1}$. For the second case:

$$
P_{1}=P-\rho g V
$$

where:

$$
\rho=\frac{P-P_{1}}{g V} .
$$

There are two ways to find the volume of a cylinder V. First:

Second:

$$
V=\frac{m}{\rho_{1}}=\frac{P}{g \rho_{1}} .
$$

$$
V=S h=\frac{\pi d^{2}}{4} h
$$

where $\rho_{1}$ is the density of steel; $d$ is the diameter of the cylinder; $h$ is the height of the cylinder.

Problem № 10 (illustrates a practical method for determining the mass of a drop of liquid). Determine the mass of one drop of water.

Equipment: pipette; a glass of water; beaker; ruler.

The solution. Drop into the beaker N drops of water to one of its divisions. Find the mass of water in the beaker according to the formula:

$\mathrm{m}=\rho \mathrm{V}$.

The mass of one drop is sought by dividing the total mass of water in the beaker by the number of drops: $m_{0}=\frac{m}{N}$.

Problem № 11 (illustrates a practical method for determining the change in fluid level when the body is immersed in it). Determine to what level the water in the beaker will rise if a piece of iron is lowered into it.

Equipment: scales with weights; iron part; thread; beaker with water, textbook.

The solution. First find the mass of the part $\mathrm{m}$, then, according to the table of densities, the density of iron $\rho$. The volume of iron parts is searched as follows: $\mathrm{V}=\frac{m}{\rho}$.

This is how much the volume of water in the beaker will change (the volume of an iron part is expressed in cubic centimeters). To find out to what level the water in the beaker will rise, add the found volume $\mathrm{V}$ to the initial water level in the beaker.

To check the correctness of the calculation, the iron part is hung on a string and lowered into a beaker of water. If the impressions are confirmed, the task is completed correctly.

Problem № 12 (illustrates a practical method of comparing the masses of different bodies). Compare the masses of two bars: copper and aluminum.

Equipment: ruler; textbook.

The solution. The masses of each of the bars are fed through their densities: 
$m_{1}=\rho_{1} V_{1}, m_{2}=\rho_{2} V_{2}$, where $\rho_{1}$ and $\rho_{2}$ are the densities of copper and aluminum, respectively (found in the textbook in the table of densities); $\mathrm{V}_{1}$ and $\mathrm{V}_{2}$ - volumes of copper and aluminum bars (measured with a ruler: multiply length by width and height), respectively. After substituting the data, the masses of the bars are compared.

Problem № 13 (illustrates a practical method for determining the length of the rod in the wood). Determine the length of the brass rod that completely occupies the hole drilled in the wooden bar.

Equipment: a wooden bar with a brass rod inserted into a blind hole drilled in it; calipers; Libra; set of weights.

The solution. The mass of the whole body can be given as the sum of two bodies: a wooden bar with a blind hole $\mathrm{m}_{1}$ and a brass rod $\mathrm{m}_{2}: \mathrm{m}=m_{1}+m_{2}$.

The mass of wood $m_{1}$ can be expressed in terms of its density $\rho_{1}$ and volume $\mathrm{V}: m_{1}=\rho_{1} \mathrm{~V}=\rho_{1}\left(V_{1}-V_{2}\right)$, where $\mathrm{V}_{1}$ is the volume of the whole bar, $\mathrm{V}_{2}$ is the volume of the brass rod, which occupies the volume of the entire blind hole.

The mass of the brass rod $\mathrm{m}_{2}$ through the density of brass $\rho_{2}$ can be expressed: $m_{2}=\rho_{2} \cdot V_{2}$.

The equation for determining the mass of the whole body will take the form: $\mathrm{m}=\rho_{1}\left(V_{1}-V_{2}\right)+\rho_{2} V_{2}$, or: $\mathrm{m}=\rho_{1}$ $V_{1}+\rho_{2} V_{2}\left(\rho_{2}-\rho_{1}\right)$.

The volume of the bar can be represented as the product of the lengths of its three corresponding edges: $V_{1}=\mathrm{a} \mathrm{b} \mathrm{c}$, and the volume of the rod due to its diameter $\mathrm{d}$ and length $\ell$ :

$$
V_{2}=\frac{\pi d^{2}}{4} \ell \text {. }
$$

After substitution receive: $\mathrm{m}=\rho_{1} \cdot \mathrm{a} \mathrm{b}$ $\mathrm{c}+\pi d^{2} \ell\left(\rho_{2}-\rho_{1}\right)$, where:

$$
\ell=\frac{4\left(m-\rho_{1} \mathrm{abc}\right)}{\pi d^{2}\left(\rho_{2}-\rho_{1)}\right.} .
$$

The weight of the whole body is sought by weighing on scales, the size of the bar and the diameter of the rod with a caliper; the values of the densities of wood and brass are taken from the table of densities. After substituting all values, find the desired length of the rod $\ell$.

Problem № 14 (illustrates a practical way to determine the volume of a metal body of complex shape). Determine the volume of an aluminum body of complex shape.

Equipment: body of complex shape; scales with weights; textbook.

The solution. Weigh the body on the scales, find the density of aluminum from the table of densities of the textbook, and the volume is calculated by the formula:

$$
\mathrm{V}=\frac{m}{\rho} .
$$

Problem № 15 (illustrates a practical method of determining the volume of a body and finding out its substance). Find the volume of the stone and its density.

Equipment: stone; dynamometer; vessel with water.

The solution. Weigh the stone twice: in the air, and find its mass $m_{1}$, and in water, and find its mass $m_{2}$. The volume of the stone will be:

$$
\mathrm{V}=\frac{m_{1}-m_{2}}{\rho_{\mathrm{B}}} .
$$

The density of the stone is found as follows:

$$
\rho=\frac{m_{1}}{V} .
$$

\section{Problem № 16 (illustrates a} practical method for determining solid matter). Determine the material from which the part is made.

Equipment: detail; scales with weights; beaker with water; textbook.

The solution. Weigh the part on the scales and find its mass $\mathrm{m}$. Then the part is immersed in a beaker and find its volume $\mathrm{V}$. The density of the part is found by the formula:

$$
\rho=\frac{m}{V} .
$$

Problem № 17 (illustrates a practical method for determining the density or type of floating body). Find the density of a piece of wood.

Equipment: a piece of wood; beaker with water; thin spitz. 
The solution. To find the mass of a piece of wood $\mathrm{m}$, it is lowered into a beaker of water: $\mathrm{m}=\rho_{\mathrm{B}} \cdot \Delta \mathrm{V}$, where $\rho_{\mathrm{B}}-$ water density; $\Delta \mathrm{V}$ is the volume of the submerged (when swimming) part of a piece of wood.

The density of a piece of wood $\rho$ is found by dividing the mass of the tree $\mathrm{m}$ by the total volume of the piece $\mathrm{V}$ :

Or:

$$
\rho=\frac{m}{V} \text {. }
$$

$$
\rho=\frac{\rho_{\mathrm{B} \Delta V}}{V} .
$$

Problem № 18 (illustrates a practical method for determining the type of bulk substances). Determine the density of sand.

Equipment: beaker; test tube; vessel with water; cup with sand.

The solution. It is assumed that the same weight of substances in the beaker will cause the same immersion. Pour a certain amount of sand, height $\mathrm{h}_{1}$ into the test tube so that it floats, and record the depth of its immersion. Pour sand out of the test tube and pour enough water into the test tube so that the immersion is to the same division. The height of the water column in the test tube will now be $h_{2}$. Ago: $m_{1}=m_{2}$.

Since: $\mathrm{m}=\rho \mathrm{V}$, then the last equation can be written differently: $\rho_{1}$ $V_{1}=\rho_{2} V_{2}$, where $\rho_{1}, \rho_{2}-$ densities of sand and water, respectively; $\mathrm{V}_{1}, \mathrm{~V}_{2}$ volumes of sand and water, respectively.

Take into account the height of the sand $h_{1}$ and the height of the water $h_{2}$ in vitro, the last entry will look like: $\rho_{1} \mathrm{~S}$ $h_{1}=\rho_{2} \mathrm{~S} h_{2}$.

Reducing the cross-sectional area $\mathrm{S}$, get: $\rho_{1} h_{1}=\rho_{2} h_{2}$.

From the obtained expression the required density of sand will be:

$$
\rho_{1}=\rho_{2} \frac{h_{2}}{h_{1}} .
$$

These tasks can be solved, one by one (10 minutes), on one of the following after studying new program questions, and the rest - on the lesson of generalization and systematization of knowledge, which is held at the end of the study section. The described organization of solving experimental problems in physics is logical, does not require spare time, allows students to master a significant number of necessary practical skills.

Conclusions and

perspectives Solving experimental problems in physics, focused on the acquisition of practical methods, ensure the implementation of an important state task for the formation of students' necessary practical skills that can be successfully used in adult life. The teacher of physics of secondary school receives tools that allow you to select from a variety of experimental tasks that directly form practical methods for the further life of students. Students are convinced of the need to solve experimental problems, because they can solve many life problems. Students' interest in the subject of physics will increase significantly.

For the prospect of further explorations, we bring a selection of experimental problems of other topics of elementary school physics, the solution of which is based on the methods necessary for human life and encourages the use of physical knowledge in life.

\section{REFERENCES (TRANSLATED \& TRANSLITERATED)}

1. Fizyka. 7-9 klasy. Navchalna prohrama dlia zahalnoosvitnikh navchalnykh zakladiv: Nakaz Ministerstva osvity i nauky Ukrainy vid 07.06.2017, № 804 [Physics. Grades 79. Curriculum for secondary schools: Order of the Ministry of Education and Science of Ukraine dated 07.06.2017, № 80]. Retrieved from https://ru.osvita.ua/school/program/p rogram-5-9/56124/ [in Ukrainian].

2. Haiduchok, H.M., Nyzhnyk, V.H. (1989). Frontalnyi eksperyment $z$ fizyky $v$ 7-11 klasakh serednoi shkoly [Frontal experiment in physics in grades 7-11 of high school]. 
Kyiv: Radianska shkola, 175 [in Ukrainian].

3. Kulyk, L.O.

Eksperymentalni

(2007).

laboratornomu praktykumi $z$ mekhaniky: metodychni rekomendatsii dlia vykladachiv ta vchyteliv fizyky [Experimental problems in a laboratory workshop on mechanics: guidelines for teachers of physics]. Cherkasy: Cherkaskyi natsionalnyi universytet, 44 [in Ukrainian].

4. Ivanenko, O.F., Makhlai, V.P., \& Bohatyrov, O.I. (1987). Eksperymentalni ta yakisni zadachi $z$ fizyky: posibnyk dlia vchyteliv [Experimental and qualitative problems in physics: a guide for teachers]. Kyiv: Rad. shkola, 144 [in Ukrainian].

5. Honcharenko, S.U.,

Korshak, Ye.V. (1998). Fizyka.

Olimpiadni zadachi. Vypusk 1. 7-8 klasy [Olympic tasks. Issue 1. 7-8 grades]. Ternopil: Navchalna knyha - Bohdan, 72 [in Ukrainian].

6. Korshak, Ye.V.,

Honcharenko, S.U., \& Korshak, N.M.
(1976). Metodyka rozviazuvannia zadach $z$ fizyky. Praktykum [Methods of solving problems in physics. Workshop]. Kyiv: Vyshcha shkola, 240 [in Ukrainian].

7. Halatiuk, Yu.M., Rybalko, A.V., \& Tyshchuk, V.I. (2007). Doslidnytski zadachi $z$ fizyky: navch. posib. [Research problems in physics: a textbook]. Kharkiv: Osnova: Triada+,160 [in Ukrainian].

8. Bozhynova, F.Ia., Kiriukhin, M.M., \& Kiriukhina, O.O. (2007). Fizyka 7 klas: pidruchnyk [Physics. Grade 7: textbook]. Kharkiv: Ranok, 192 [in Ukrainian].

9. Korshak, Ye.V., Liashenko, O.I., \& Savchenko, V.F. (2014). Fizyka. 7 klas: pidruchnyk [Grade 7: textbook]. Kyiv: Heneza, 168 [in Ukrainian].

10. Syrotiuk, V.D. (2015). Fizyka: pidruch. dlia 7-ho $\mathrm{kl}$, zahalnoosvit. navch. zakl [Physics: a textbook for 7 th grade secondary schools]. Kyiv: Heneza, 240 [in Ukrainian].

Received: June 25, 2021 Accepted: August 03, 2021 